\title{
Universiteit
}

Leiden

The Netherlands

\section{Female Critics of Islamism: Liberal or Secular Islam?} Cliteur, P.B.

\section{Citation}

Cliteur, P. B. (2011). Female Critics of Islamism: Liberal or Secular Islam? Feminist Theology, 19(2 January), 154-168. Retrieved from https://hdl.handle.net/1887/20654

Version: $\quad$ Not Applicable (or Unknown)

License: $\quad$ Leiden University Non-exclusive license

Downloaded from: $\quad$ https://hdl.handle.net/1887/20654

Note: To cite this publication please use the final published version (if applicable). 


\section{Female Critics of Islamism: Liberal or Secular Islam?}

\author{
Feminist Theology \\ 19(2) 154-167 \\ (C) The Author(s) 20II \\ Reprints and permission: sagepub. \\ co.uk/journalsPermissions.nav \\ DOI: I0.II 177/09667350I0384328 \\ fth.sagepub.com
}

@SAGE

\title{
Paul Cliteur
}

\begin{abstract}
The author distinguishes between two types of criticism of Islamism: 'liberal Islam' and 'secular Islam'. The meaning and consequences of this difference in approach is analyzed with reference to the work of Chadortt Djavann, Irshad Manji, Mina Ahadi and Taslima Nasreen. The difference of approach is especially relevant in the way one looks at 'interpretation'. This will be illustrated by analyzing a discussion between Tariq Ramadan and Ayaan Hirsi Ali.
\end{abstract}

\section{Keywords:}

feminism, interpretation, Islam, Islamism, violence against women

In the Western world, but also within Muslim countries, there is an intense debate about what could be called the compatibility of Islam (or Islamism) with liberal-democratic values (Mayer, 2007; King, 2009). At least since Susan Moller Okin's influential essay, 'Is Multiculturalism bad for Women?' (1999) political commentators, scholars and activists have discussed the question of whether the cultural practices of religious minorities in Western liberal democracies (in particular Islamic minorities) are compatible with emancipatory ideals like the equal treatment of men and women as enshrined in human rights treaties and constitutions.

Two years later 9/11 occurred and a whole new range of questions came to the fore with as the most prominent whether radical and violent Islamic fundamentalism poses a threat to international security and what can be done about this (Tibi, 2008; Phares, 2007; Guiora, 2009; Ellian, 2008).

Both of these discussions are related in the sense that most commentators conclude that religion has to be 'reformed' (Kamrava, 2006; Donohue and Esposito, 2007). Most commentators contend that Islamic fundamentalism, radical Islam, political Islam,

\section{Corresponding author:}

Paul Cliteur

Email: paulcliteur@gmail.com 
Salafism, Wahhabism, Islamism - this semantics is not limitative-poses a challenge that has to be met. The next question, though, is how? And subsequently: who is most likely to do this?

In answer to the first question ('how do we oppose Islamic fundamentalism?') there are two approaches to be distinguished. The first approach is that of what could be called the stimulation of 'liberal Islam' or 'moderate Islam'. The advocates of 'liberal Islam' usually say that Islam has been 'high-jacked' by the radicals. What should be done is that 'the radicals' should be exposed for what they are: inauthentic defenders of the faith (Abou El Fadl, 2007). The second approach I would like to qualify as 'secular Islam'. Defenders of the secularist approach seem inclined to delve deeper into the religious roots of discrimination and violence. They appear inclined to consider Islam in the same way as every other religion: it has to be subjected to the constitutional principles of the secular state. There is religious freedom, but only insofar as this does not infringe the secular constitutional and democratic order (Tibi, 2009). The proposals to modify religion by the 'secularists' are more far-reaching and subsequently met with more hostile reactions, not only from orthodox religious circles but from the society at large as well.

The two epithets of 'secular Islam' and 'liberal Islam' seem to me useful to understand a difference in opinion between those reflecting on how to deal with religious fundamentalism.

The 'liberals' reproach the 'secularists' for attacking religion too severely. The secularist position is de facto 'anti-religious', they say. Defending such an 'anti-religious' stance is also considered to be 'counterproductive' or 'not helpful'. Change has to come 'from within'.

The 'secularists' reproach the 'liberals' that they are too pussyfooting in criticizing religious dogmas, in particular the religious dogma of scriptural authority. As long as the dogma of scriptural authority is left intact the only way to liberalize religious traditions is by means of 'interpretation'. And because holy scripture (Koran and Bible alike) does indeed contain moorings for violence (also religious terrorism, see on this: Selengut, 2003; Haught, 1995) and the unequal treatment of categories of citizens now generally considered to be equal (men and women, homosexuals and heterosexuals), emancipation and an effective counterterrorist strategy will make little headway.

It is important to understand that 'secular Islam' and 'liberal Islam' stand for two broad designations about how to deal with Islamist fundamentalism. They are not necessarily characterizations of what individual believers actually believe themselves. One can be an advocate of 'liberal Islam' without being a Muslim. This is the case with most Western participants on this debate. One can also be an advocate of 'secular Islam' without being a Muslim.

In this article I focus on Islam or Islamism. The reason for that is not that other religions have not frustrated emancipation or are purely peaceful (Rapoport, 1984, 1988). On the contrary, much of what we find in the Islamic tradition has counterparts in the Jewish and Christian tradition (Juergensmeyer, 1998). Nevertheless, the actual significance of Islamist terrorism is undoubtedly greater than Jewish or Christian terrorism.

Finally: I will treat the subject of secular Islam and liberal Islam by also giving an implicit answer to the second question I have identified before: the question of who is to do the reforming? 
It does not seem premature to predict that women will have an important role in this process (Reed, 2002). While in the previous generation reforming Islam or Islamism was a matter for male scholars, the last decade has presented us with a whole group of female writers who entered upon the stage (inspired by a previous generation as we can make up from the work of Mernissi, 1983, 1992, and Saadawi, 2007). Within that group of female writers the division sketched above between 'liberal Islam' and 'secular Islam' is clearly noticeable. Some defend the 'liberal' option, others the 'secular' approach.

In the pages that follow I will try to do two things. First I will give an impression of four female reformers of Islamism from different national backgrounds: Chahdortt Djavann (France), Irshad Manji (Canada), Mina Ahadi (Germany) and Taslima Nasreen (Bangladesh). Those reformers are, with the sole exception of Irshad Manji, from the 'secularist' type. Second, I will enter into the discussion on whether 'liberal Islam' or 'secular Islam' has the best chance of bringing about the reform that everybody hopes for. This second part I will illustrate by analyzing a debate in the newspapers between the Islam reformer Tariq Ramadan and the feminist former politician (in the Netherlands) and currently public intellectual Ayaan Hirsi Ali (in the USA). Ramadan is a clear representative of the 'liberal' or 'moderate' Islam version; Hirsi Ali of the secularist approach. In some concluding chapters I will also try to gauge what position is most likely to have fortunate effects in integrating religion into the liberal-democratic order and of developing an effective counterterrorist strategy.

\section{Djavann, Ahadi, Manji and Nasreen}

A tough stance against Islamism defines the approach of the French novelist and public intellectual Chahdortt Djavann (1967- ). Djavann gained notoriety as a public intellectual with a pamphlet against the Islamic veil: Bas les voiles (2003) or 'Down with the veil'. One year later she presented a more comprehensive vision on the tension between Islam and modernity: Que pense Allah de l'Europe (2004) or 'What does Allah think of Europe?' In 2007 she also presented an analysis of one of the most important seedbeds of Islamism: the Iranian Republic. She is also known as a novelist (Djavann, 2006, 2008).

As indicated, Djavann vehemently opposes the veil. There never was an innocent veil, she writes. The veil has always meant the submission of women to men. It symbolizes the non-existence of rights for women in Islamic countries, the reduction of women to a sexual object that may be appropriated (Djavann, 2004: 23). But is the veil not a personal choice, as many liberal intellectuals object? Or at least a much more ambiguous symbol than merely a sign of suppression? Partly, perhaps. But that should not bring us to the conclusion that there is nothing wrong with it. Slavery was also part of the oriental culture, but that should not bring us to a defence of this abhorrent practice. And fascism, anti-Semitism, racism may all be based on personal choices, but that should not make those choices respectable (Djavann, 2004: 25). Gradually Djavann developed a wholesale critique on Islamism as inimical to the central tenets of liberal democracy. The world of Islam does not allow philosophical pluralism ('Le monde musulman n'admet pas la pluralité philosophique'), and she has high expectations from the secularist philosophers from the seventeenth, eighteenth, and nineteenth centuries (2004: 80). 
The Canadian feminist and critic of Islamism, Irshad Manji (1968- ), is certainly not one of those secularists Djavann mentions. On the contrary, Manji makes several critical remarks about those secularists. Yet, she is a comrade in arms as far as the reform of Islam is concerned. Manji is more in the tradition of 'liberal Islam' than 'secular Islam'.

Manji was born in Uganda and published in 2004 a highly successful book, The Trouble with Islam. It has been translated into more than 30 languages, including Arabic, Indonesian, Urdu, Malay and Persian. Characteristic of Manji, if compared with related authors presented here, is that she wants to remain within the Islamic tradition. She stipulates that she herself is not an 'infidel', but a believer. Nevertheless, she points her arrows at the same sort of bigotry and suppression that Djavann and other women writers castigate. She asks: 'Why are we squandering the talents of women, fully half of God's creation? How can we be so sure that homosexuals deserve ostracism - or death - when the Koran states that everything God made is “excellent”?' (Manji, 2003: 2).

What Manji tries to accomplish is getting Muslims away from a literal reading of the Koran: 'What's our excuse for reading the Koran literally when it's so contradictory and ambiguous'?

This sentence is essential for a proper understanding of the aims of the group of thinkers advocating 'liberal Islam'. They have high expectations of interpretation. Not holy texts as such are the problem, but our interpretation of these texts. She characterizes her own position as 'a Muslim Refusenik'. That does not mean that she refuses to be a Muslim, but that she refuses 'to join the army of automatons in the name of Allah' (Manji, 2003: 3).

What is necessary to accomplish this is what she, in harmony with Islamic vocabulary, characterizes as the opening of 'the gates of ijtihad'. Ijtihad is independent thought. Independent thought was smothered in Islamic culture. The gates of Ijtihad were closed in the twelfth century when the muftis were gaining the power to patrol the truth, Manji tells us (2003: 145). But there is a great hunger for change. Manji indicates she feels assured that she is 'not the only Muslim who hungers to hear freethinkers candidly debate their truth and pertinence on the airwaves' (2003: 169).

But although Manji is, in her ambition to reform Islam and criticize the conservative elements of the clerics, in line with her fellow female critics of Islamism, she keeps them at arms length as far as their secularism is concerned. She refers to Taslima Nasreen whose work will be discussed below, who adamantly believes that reform will emerge 'only when religion retreats' (Manji, 2003: 169). Muslims need to replace religious laws with civil ones, completely separating mosque and state, Manji tells us, paraphrasing the ideas of her fellow reformer Nasreen. But Manji chooses something different. As an explication of her position she refers to an uneducated Afghan woman who will not be very responsive if you asked her whether she is in favor of human rights. If you ask that same woman, though, whether she believes in God, she will give an affirmative answer. And if you ask her: 'Do you think that God is just and merciful?', her answer will be 'yes'. So that last idea is a better mooring for the struggle against female beatings than the first one. Women do not necessarily have to subscribe to Nasreen's 'dogmatic secularism', as Manji calls it (2003: 170).

This strategy, so it seems, calls for some further explanation. What is 'dogmatic' about Nasreen's atheism, Manji does not make sufficiently clear. Advocates of 'moderate' or 'liberal' positions tend to portray the defenders of what I have called the 'secularist' 
approach as 'dogmatic', but the question is: is that justified? What is 'dogmatic' about saying that you do not believe in God, for instance? Or that you do not base you morals on divine revelation?

But apart from that, the position defended by Manji herself seems to have some drawbacks as well. Manji refers to the 'uneducated Afghan woman who will not be responsive if you ask her whether she is in favor of human rights' and who would be if you ask her 'whether God is just and merciful'.

This is a purely strategic argument. But is that strategy as good as it seems? That can be doubted, because once a 'liberal' believer has confided to an Afghan woman that he or she is addressed in the vocabulary of religion for pragmatic reasons only that woman will never believe a word of what is told to her. The problem with religious liberals advocating a liberal reading of Holy Scripture for strategic reasons (or on pragmatic grounds) is that all their interpretations will appear immediately suspect once the reasons for their approach of Scripture becomes generally known (which is mostly the case with writers who, from the nature of their profession, seek publicity). The only consistent way to be a liberal believer and still honour integrity, it seems, is really believing that, for example, incitements to violence in Scripture do not hold and all exhortations to generosity, love of mankind and compassion reflect some way or another the true will of God. But who could believe such a thing?

Nevertheless, for all the shortcomings of her methodology, Manji's advocacy of free speech, or what the French call 'libre examen', stands unsurpassed, and here she clearly belongs to the group of women critics reforming Islam. She even defends the rights of Oriana Fallaci (1929-2006) in her rants against Muslims (Fallaci, 2004, 2002) and Michel Houellebecq's (1958- ) right to call Islam 'the most stupid religion' (Manji, 2003: 182) - something most authors would hesitate to do. She is also very explicit in denouncing multiculturalism with its concomitant cultural relativism. She approvingly cites the French author Amin Maalouf (1949- ) who wrote: 'Traditions deserve to be respected only insofar as they are respectable - that is, exactly insofar as they themselves respect the fundamental rights of men and women' (Manji, 2003: 199).

A third woman writer critical of Islamism is the German intellectual and social activist from Iranian descent, Mina Ahadi (1956- ). Ahadi seems more in the tradition of secular Islam than liberal Islam. She is an important figure within the Central Committee against stoning and a member of the German Council of Ex-Muslims. Her explicitly secular orientation makes her more similar to Djavann than Manji. What she has in common with both authors, though, is that she presents her critique as aimed at the empowerment of women. She holds the emancipation of women as the focal point of a free society. In particular she is interested in the plight of women who are under threat because they run the risk of being stoned on the basis of presumed violations of holy law.

What is implicit in Manji's critical remarks about the followers of Said is more explicit in Ahadi's work. She is critical about 'engagierte Linke', especially for what they have on their conscience with regard to tolerance of the intolerant. All kinds of oppression, as in the case of honour killings, are accepted by the members of the 'engaged left' on considerations of political correctness (Ahadi, 2008: 8). But those crimes in the name of religion should no longer be excused as parts of 'another culture' that cannot be criticized, she claims (Ahadi, 2008: 21). 
She tells us that she has nothing against religion as a private conviction. The only limit should be that articles of belief do not violate the liberal-democratic order or human rights. Her problem is the actual brand of Islam. That specific form is not reformable ('Ich halte den Islam in seiner heutigen Form nicht reformierbar', [Ahadi, 2008: 9]). Therefore she decided to quit the fold ('Deshalb habe ich abgeschworen, wie bis heute fast 200 mitstreiterinnen und Mitstreiter', [Ahadi, 2008: 9]).

This is different from what Manji and many other critical Muslims contend. Manji and other liberal or moderate Muslims would undoubtedly say that with this strategy you give up all hope that Islam can be reformed from within. And that Islam should from within go through a process of Enlightenment, Ahadi herself tells us; the same process Christianity has gone through in the last few centuries. But if you leave Islam yourself, the moderate Muslim will answer Ahadi, how can you contribute to this process?

The fourth and final author I want to refer to is Taslima Nasreen (1946- ). Taslima Nasreen (or Nasrin) is a Bengali ex-physician, feminist and literary writer who became notorious for her critical stance against Islam and Islamism, although she is also critical of other religions, for example Hinduism. Due to persistent death threats she lived for many years in exile and remained in undisclosed locations in India and other countries. In March 2008 she planned to leave India due to health problems. She suffered from high blood pressure and cardiac distress. On 18 March 2008 she was treated in a cardiac clinic in Sweden. In February 2009 she received asylum in Paris.

Nasreen's problems with radical religionists and the Indian and Bengali government, unable or not prepared to protect her effectively, started with the publication of her novel Lajja (Shame) in 1993. The novel, deemed to be blasphemous, was banned by the government of Bangladesh. Soon after, Nasreen had to leave the land and embark on a life in exile. Nasreen's most important goal in her work is the fight against women's oppression. She said: 'from the dawn of civilization, humans have been guided by society and religion. Society and religion have always been owned and directed by men in every age. State and society surely, but religion too, had forever dishonoured women' (Nasreen, 2004: 2). Nasreen lives a very unquiet life, but she does not complain, she once said. She considers herself lucky that no one has, as yet, burnt her face or blinded her eyes with acid. She feels fortunate that no gang of men have raped her. And most of all: she is still alive. Nevertheless, she is hounded by extremists. Why? 'The crime for which I am persecuted? I am a woman' (Nasreen, 2004: 2). In this country, she says, talking about Bangladesh, 'no amount of ability can raise women to the level of a human being' (Nasreen, 2004: 2).

Nasreen also criticizes the Hudood laws. Hudood law was intended to implement Sharia law, by enforcing punishments that are mentioned in the Koran and the Sunnah in relation to among other things extramarital sex (Gozlan, 2002: 128). On 20 February 1979, Pakistan issued the Hudood laws against theft, alcoholism, adultery, rape and perjury (Nasreen, 2004: 69). Punishments are extremely severe. Nasreen also reveals the strange laws about rape: allowing only male testimony in a rape case means shielding the culprit. In an ordinary rape case (not gang-rape) it is unlikely that there are four men witnessing the scene who could later testify to what had happened (Nasreen, 2004: 70). 'Sacred texts, as well as society, teach a woman should not have freedom. But a woman is incomplete till she is free in body and mind' (Nasreen, 2004: 94). 


\section{An Assessment of the Women Critics of Islamism}

My list of female critics of Islamism (Djavann, Manji, Ahadi and Nasreen) is not meant to be exhaustive. There are other examples as well. One only has to think of the work of Seyran Ates (2006, 2007), Ayaan Hirsi Ali (2006, 2007), Necla Kelek (2005, 2007), Mimount Bousakla (2002), Nahed Selim (2003, 2007a, 2007b ), Nonie Darwish (2007, 2008), Brigitte Gabriel (2008), Wafa Sultan (2009) and others to realize that with these four names the new movement of female critics of Islamism is far from exhausted. But my aim is not to be conclusive but to give an impression of a new wave of women writers in their struggle to liberate the Islamic tradition from some of the nasty practices and currents connected with it.

There is much common ground between the female critics of Islamism. They all agree that some elements of Islam or Islamism need to be reconsidered. There is an important difference, though, and this is about liberal Islam versus secular Islam. Manji is a case in point. What Manji distinguishes from the other commentators presented here is that she wants to focus on 'radicalism' but not on 'religion itself'. What distinguishes the 'moderates' or 'liberals' from the 'secularists' is not a difference in values, but in approach and strategy. The 'moderates' want to avoid criticism of religion in itself and want to focus on some cultural practices of the religion that is - so to speak - not the 'essence' or 'core' of the religion itself. The secularists on the other hand want to identify some elements of the religion itself and modify these.

In the following pages I want to further elaborate on this distinction and show what the distinction between 'moderates' and 'secularists' means for an important subject: the interpretation of Holy Scripture. To illustrate that difference I can best refer to a specific discussion that has taken place between two vocal representatives of both traditions. The first is a contemporary reformer of Islam, Tariq Ramadan. The second is a female critic standing in the tradition of Djavann, Ahadi and Nasreen: Ayaan Hirsi Ali. The discussion is about how to deal with religious violence against women. Can we adequately deal with this by giving a different 'interpretation' of the clauses in the holy book that seem to sanctify religious violence? Or should be go further and criticize religious authority as such?

This is the same issue we have discussed before in relation to the ideas of Irshad Manji. This discussion is at the heart of the controversy between liberal Islam and secular Islam.

\section{Liberal Islam and Secular Islam on Interpretation}

The focus of the debate between Ramadan and Hirsi Ali is on the relation between religion and violence. In the Koran (24:2) there is a passage on adultery and fornication. The passage runs as follows: 'The woman and the man guilty of adultery or fornication, flog each of them with 100 stripes: Let no compassion move you in their case, in a matter prescribed by Allah, if you believe in Allah and the Last Day.'

This passage is quoted by Ayaan Hirsi Ali (1969- ), a former Dutch politician and at present fellow of the American Enterprise Institute, in an article on a 20 year-old woman from Qatif, Saudi Arabia, reported to have been abducted by several men and repeatedly raped. Judges found the victim to be guilty herself. Her crime is called 'mingling'. When 
she was abducted the woman was sitting in a car with a man not related to her by blood or by marriage. This is illegal in Saudi Arabia. She was sentenced to 200 lashes with a bamboo cane (Hirsi Ali, 2007a).

For many people this sentence will be seen as draconic, outrageous or at least unjust. Why is the woman sentenced in this harsh way? Why is she punished at all? Because the Saudi law prescribes this sentence for this specific offence, could be the answer. But why is the Saudi law so cruel in this matter? Judging from the fact that Hirsi Ali starts her article with a specific passage from the Koran her stance does not leave much room to speculate: she thinks that the passage in the Koran has something to do with the way people think, behave and in this case judge (or sentence) in Saudi Arabia. What Hirsi Ali wants with her article, obviously, is to make people aware of the cruel passages in the holy book. She also argues that those passages inhibit the moral evolution of the people living under the guidance of the holy book. But she not only criticizes the book, the judges and the Saudi penal system but also, as appears from her article, the so-called 'moderate' adherents of the religion. She criticizes them for two reasons.

The first is that the 'moderates' do not speak out clearly against those atrocious acts. The second reason for criticizing the 'moderates' is because they obfuscate the relation between the passage of the holy book and the social practice that is - according to Hirsi Ali-based on that book or at least influenced by that book. As one of the most vocal spokesmen for that moderate approach she refers to the well-known Muslim scholar Tariq Ramadan (1962- ). ${ }^{1}$

Ten days later Ramadan answered her indictment in a rejoinder quoting the same passage from the Koran as Hirsi Ali had done. In his reply Ramadan gave a defence of his position that seems characteristic of a widely dispersed attitude towards religious criticism among contemporary intellectuals, even those critics who are willing to advocate reform within the Islamic tradition. Ramadan's answer seems to be illustrative of what we could call the 'moderate' approach of religious criticism. That 'moderate' approach does not criticize the text directly, but only the 'interpretation' of the text. Here we have an important difference with the secularist approach. Let us hear what Ramadan has to say. He writes:

What kind of message does she [Hirsi Ali] exactly want to convey by quoting a verse referring to corporal punishment? That Islam, per se, is advocating violence? That violent Muslims or the so-called Islamic governments acting undemocratically are in fact genuinely implementing the Islamic message? Through her text, the message becomes clear: Islam is an archaic religion, the Koran is a violent text and the only way to reform Islam is simply to "deislamisize" the Muslims (Ramadan, 2007).

1 Ramadan is often criticized for an alleged double agenda. I will not enter into this subject and only comment on what he writes in response to Hirsi Ali in the newspaper article indicated before. See on the discussion on Ramadan in general: Fourest C (2004) Frère Tariq. Discours, stratégie et méthode de Tariq Ramadan Grasset. Paris: Bernard Grasset ; Landau P (2005) Le Sabre et le Coran. Tariq Ramadan et les frères musulmans à la conquête de l'Europe. Paris: Éditions du Rocher; Berman P (2007) Who is afraid of Tariq Ramadan? The islamist, the journalist, and the defense of liberalism. The New Republic, 4 June: 37-62. 
Ramadan advances some implications of the reasoning of Hirsi Ali that seem to him simply unacceptable or unwelcome. Let us analyze the most important aspects of Ramadan's answer.

First, Ramadan asks 'what kind of message does she exactly want to convey by quoting a verse referring to corporal punishment?' But the message conveyed by Hirsi Ali is not too difficult to understand, so it seems: passages in the Holy Book do actually influence behavior. That is what she wants to say. This is also the message of critics of Islamism with a similar approach: Djavann, Ahadi and Nasreen. To determine whether they are right we have to pose the question whether Sura 24:2 is indeed the basis of or, to put it more cautiously, influential on the Saudi penal system and the harsh punishments it inflicts on Saudi women. What (if any) is the direct or indirect impact of Sura 24:2 on the ideas of the Saudi judges and the Saudi law?

Ramadan does not address that question unswervingly. Instead he directs the attention away from Islam. In an elaboration of the passage quoted before he writes:

Would it not be possible to quote here tens of passages from the Bhagavad Gita, the Torah, the Gospels and the Epistles that are violent without reaching the conclusion that Hinduism, Judaism or Christianity are violent per se? Is it difficult to understand that this is a question of interpretation and that to condemn in such a way a religion, by its very essence, is not only unjust but deeply counterproductive? It does not help the inner dynamic of reforms (Ramadan, 2007).

This answer is illuminating because it illustrates the basic difference in the approach of those who favour 'liberal Islam' or 'moderate Islam' on the one hand and those who advocate 'secular Islam' on the other. His first explicit contention in this second quote from Ramadan's article is that there are violent passages from the holy books of other great religions. That necessitates two questions. First: is this true? Second: is it relevant?

Would it be possible, for instance, to quote from the Gospels, as Ramadan explicitly contends, passages from which it appears that Jesus Christ is in favour of the same harsh punishments as indicated in Sura 24:2? On this point Ramadan does not provide examples but supposes this to be the case. One may doubt whether it is possible to provide examples from the Gospels that are similar to the one quoted from the Koran, but that it would be able to quote those passages from the Old Testament seems clear (see for e.g. Deut. 13.5-6). The most important question, however, is something else. It has to do with the relevance of his response. The main problem, so it seems, is that it is no answer to Hirsi Ali's indictment. The fact that other religions prescribe violent behaviour as well as Islam does, does not exonerate Islam. What Ramadan seems to do is accuse Hirsi Ali of selective indignation. His message seems to be: 'because other religions are violent you have to castigate them all before you have the moral right to criticize one specific religion, i.e. Islam.' But that seems not a strong defence for the simple reason that the direct occasion for Hirsi Ali's criticism was the Saudi woman convicted of 'mingling'. If the whole discussion could have been ignited on occasion of an imminent flogging of a Jewish woman in Israel convicted in a Jewish Court, the whole discussion should focus on the Old Testament and whether the Israeli judges could have been influenced by passages 
from Deuteronomy or other notorious examples of violent texts in the Old Testament. But this was not the case.

In other words: it is not the violent passages from the holy book that are the focus of our attention, it is the combination of scriptural authority with contemporary social practices. Scriptural passages advocating violence that are not heeded by believers in the twenty-first century because they are considered to be some kind of poetry give us less cause to worry.

\section{Religion 'per se'}

There is a second point that Ramadan addresses. This second point is only made in passing in the first quote from his article, more by way of suggestion than explicit argumentation. He seems to insinuate that although it may be possible to quote violent passages from holy books and holy traditions, it is not justified to conclude from this that those religions are violent 'per se'. This may seem a trifling distinction but in fact it is very important indeed. Ramadan suggests that we should distinguish between, first, the actual consequences that are drawn from a religion and some passages in the holy book and, second, 'religion per se'. And 'religion per se' in his worldview seems to be something that remains untouched by the social manifestations of that religion and the possibly violent passages in the text of revelation. I therefore propose to dub this the 'metaphysical conception of religion' in contrast to what one could label the 'empirical conception of religion'. What worries Ramadan is that Hirsi Ali apparently refuses to subscribe to the metaphysical notion of religion, to the idea that there is a religion 'per se'. Hirsi Ali is indicted of playing a false game: she wants to judge and possibly reject a religion on the basis of its unwelcome manifestations, the contents of its holy books, the attitude of its believers, whereas according to Ramadan we have to judge a religion on what might be called its 'per se-character' or its metaphysical dimension.

In introducing this pristine and metaphysical 'per se'-notion of religion, always unaffected by the vicissitudes of religion in this empirical world, Ramadan and other 'moderate' or 'liberal' believers make some metaphysical claims that need to be studied and analyzed thoroughly. But so long as this has not been done, it seems justified not to adopt that notion. The empiricist of religion will say: there is no 'religion per se' apart from the manifestations of that religion. A religion is what is written about that religion in the book and what the believers act upon. There is no 'religion per se' distinct from the texts of the holy book and the behavior of its acolytes. The metaphysical approach of religion has to be rejected. The group of critics that I have identified as the advocates of 'secular Islam' are predominantly 'empirical' in their approach. Advocates of 'moderate' or 'liberal' positions, on the other hand, tend to think that 'religion in itself' or 'religion per se' (as Ramadan calls it) is necessarily good. This is a kind of metaphysical conviction, and judged on the basis of the tenaciousness of their adherents almost 'religious' in nature, so it seems to me (although it is never presented as such and also not recognized as such).

Perhaps these distinctions will strike the reader as overly subtle, 'scholastic' or whatever you may want to call them. The fact that I have to introduce them, though, is because the 'per se'-notion of religion is enormously influential. As a matter of fact, these distinctions 
are not specifically mine. They are made and held by writers like Ramadan himself, although unconsciously and without an idea of their dubious character. That there is a 'religion per se' apart from the social manifestations of a religion is presupposed by many people active in this debate.

Once we have adopted the idea that religion is from the nature of the concept something good, and evil only comes into this world by means of the wrong interpretations, we only have to 'reinterpret' religious traditions to get the result we desire. This presupposes, of course, that interpretation can perform this 'trick'.

As we have seen before, Irshad Manji is very sanguine about this and the same is true of Tariq Ramadan. They seem both to be under the spell of the postmodern conviction that Scripture has no authority over us in the sense that we are not forced to a certain interpretation on behalf of the content of the text. In the Western world under the aegis of postmodernism we are almost all 'textualist relativists' in the sense that we think that we can interpret texts any way we like. This textual relativism is intimately related to a more general form of relativism (see, Scruton, 2007: 75) made popular by intellectuals such as Michel Foucault (1926-1984) and among earlier thinkers like Friedrich Nietzsche (1844-1900). That Ramadan also writes under the spell of this typically postmodern conviction is clear from the rhetorical question following on the introduction of his 'per se'-notion of religion. 'Is it difficult to understand', he asks in a rhetorical way in the first passage I quoted from him with regard to the matter of the violent character of religion, 'that this is a question of interpretation (...)'?

At the end of the nineteenth century Nietzsche criticized positivism. The reason was that there are no 'facts', as positivists supposed, only 'interpretations' ('Gegen den Positivismus, welcher bei den Phänomenen stehn bleibt "es gibt nur Tatsachen”, würde ich sagen: nein, gerade Tatsachen gibt es nicht, nur Interpretationen'; Nietzsche, 1969: 495).

It may safely be said that these words have had a disastrous influence: especially because Nietzsche added that we do not even have to try to establish facts ('vielleicht ist es Unsinn, so etwas zu wollen'; Nietzsche, 1969: 495). It led people to believe that words can mean anything we want them to mean.

\section{Can Interpretation Mitigate All Immoral Passages in Scripture?}

The point that Ramadan makes with regard to interpretation is also made for translation. Anyone who has discussed scriptural authority (with believers and unbelievers alike) knows that many of them, if confronted with violent texts from their revelatory sources, react with the contention that the violent character of the text is only superficially there. That has to do with the 'translation' of the text. Usually that remark is followed by the good advice of the believer to look for a more reliable translation. And, of course, translations matter. The text that Hirsi Ali and Ramadan refer to in their exchange of views can be translated in different ways. This notorious Sura 24:2 is translated, for instance, by NJ Dawood as follows:

The adulterer and the adulteress shall each be given a hundred lashes. Let no pity for them cause you to disobey God, if you truly believe in God and the Last Day; and let their punishment be witnessed by a number of believers (The Koran, tr. Dawood: 246). 
This translation is slightly different from the one quoted by Hirsi Ali. But does that help the apologists of religion? The answer is clearly negative. The differences between the translation of Dawood and the one used by Hirsi Ali and Ramadan are marginal, as we can see, and that may be expected when we remember that many scholars have carefully thought about those translations. So what could help the apologist of religion with regard to Sura 24:2 is not 'translation', it has to be 'interpretation'. And it is from 'interpretation' that Ramadan has high expectations, judging from his rhetorical exclamation: 'Is it difficult to understand that this is a question of interpretation $(\ldots)$ ?'

But can 'interpretation' do what Ramadan supposes it can do? Even a provisional glance over the text makes that improbable. Nevertheless, let us start with the most promising element: an interpretation of 'adulterer' or 'adulteress'. Why is the Saudi woman characterized as an 'adulteress'? The only thing she has done is 'mingling': sitting in a car with someone who is not her husband or her direct family. Is that adultery?

According to the Concise Oxford Dictionary adultery means: 'Voluntary sexual intercourse of married person other than with spouse'. Because in this case there is no mention of sexual intercourse, there is no adultery, so it seems. So the Saudi judges gave the wrong interpretation to Sura 24:2, the 'moderate' could answer. Would that help us out of this quandary?

Not quite. First, we have to remember that what we have done with the passage in Sura $24: 2$, is force our contemporary ideas on adultery onto a completely different situation. The Concise Oxford Dictionary simply follows contemporary semantic meaning. 'Adultery', according to an ordinary dictionary, is what most people of the languagecommunity nowadays mean when they use the word. But that is likely to be different from what people mean by 'adultery' in Saudi Arabia. It is also very different from what people meant in the time and the culture which established the text of the Koran. So an 'interpretation' of what the word 'adultery' means in the Koran, according to the modernist strategy, is more similar to a revision of the Koran than an 'interpretation'.

Nevertheless, if we follow the somewhat dubious approach of reading contemporary meanings into ancient texts there is some hope for modern 'minglers'. I underscore 'some', in contradistinction to 'much'. Because there is not much fantasy needed to change the situation a little to see what I mean. Suppose the Saudi woman did indeed have sexual intercourse with the man in the car: in that case the punishment as described in Sura 24:2 had to be executed. Would that make our opposition to the text less urgent? The answer is clear: even in the case of actual sexual intercourse we are not in favour of one hundred lashes. So the problem is not the 'interpretation' of this text. The problem is the text itself.

Moderates are inclined to deny this. For them, as for Ramadan, the problems that arise are always perceived as problems concerning the 'interpretation'. Therefore they never do what should be done to remedy our problems: demystifying the idea of scriptural authority itself. The problem is not that people give a conservative interpretation to a religion that is 'per se' pristine and incorruptible, but that people think that they can defer their modern conscience to ancient texts. We may also put it thus. The problem is (a) the content of the text itself and (b) the attitude of the people who think that they should follow ancient texts. 


\section{References}

Abou El Fadl K (2007) The Great Theft: Wrestling Islam From the Extremists. New York: Harper SanFrancisco.

Ahadi M (mit Sina Vogt) (2008) Ich habe abgeschworen: warum ich für die Freiheit und gegen den Islam kämpfe. München: Heyne.

Ates S (2006) Grosse Reisse ins Feuer: Die Geschichte einer deutschen Türkin. Berlin Rowohlt. Ates S (2007) De Multikulti-Irrtum: Wie wir in Deutschland besser zusammenleben können. Berlin: Ullstein.

Berman P (2007) Who is afraid of Tariq Ramadan? The islamist, the journalist, and the defense of liberalism. The New Republic, 4 June: 37-62.

Bousakla M (2002) Couscous met frieten. Antwerpen: Houtekiet.

Darwish N (2007) Now They Call Me Infidel: Why I Renounced Jihad for America, Israel, and the War on Terror. London: Sentinel, Penguin Books.

Darwish N (2008) Cruel and Unsual. Thomas, Nashville: Nelson.

Djavann C (2003) Bas les voiles! Paris: Gallimard.

Djavann C (2004) Que pense Allah de l'Europe? Paris: Gallimard.

Djavann C (2006) Comment peut-on être français? Paris: Flammarion.

Djavann C (2007) À mon corps défendant l'occident. Paris: Flammarion.

Djavann C (2008) La Muette. Paris: Flammarion.

Donohue JJ, Esposito JL (eds) (2007) Islam in Transition: Muslim Perspectives. Second Edition. New York /Oxford: Oxford University Press.

Ellian A (2008) Monotheism as a political problem: political Islam and the attack on religious equality and freedom. Telos 145 (Winter): 87-102.

Fallaci O (2002) La Rage et l'Orgueil. Paris: Plon.

Fallaci O (2004) La Force de la Raison. Paris: Rocher.

Fourest C (2004) Frère Tariq. Discours, stratégie et méthode de Tariq Ramadan Grasset. Paris: Bernard Grasset.

Gabriel B (2008) They Must Be Stopped: Why We Must Defeat Radical Islam and How We Can Do It. New York: St. Martin's Press.

Gozlan M (2002) Pour comprendre l'intégrisme islamiste. Paris, Espaces libres, Albin Michel.

Guiora AN (2009) Freedom From Religion: Terrorism and Global Justice Series. Oxford: Oxford University Press.

Haught JA (1995) Holy Hatred: Religious Conflicts of the '90s. Amherst, NY: Prometheus Books. Hirsi Ali, A (2006) The Caged Virgin: An Emancipation Proclamation for Women and Islam. New York and Sydney: The Free Press.

Hirsi Ali A (2007a) Islam's silent moderates. The New York Times, 7 December.

Hirsi Ali, Ayaan (2007b) Infidel. London: The Free Press.

Juergensmeyer M (1998) Christian violence in America. Annals of the American Academy of Political and Social Science 558: 88-100.

Kamrava M (ed.) (2006) The New Voices of Islam: Reforming Politics and Modernity-A Reader. London/New York: I.B. Tauris.

Kelek N (2005) Die fremde Braut: Ein Bericht aus dem inneren des türkischen Lebens in Deutschland. Köln, Kiepenheuer \& Witsch. 
Kelek N (2007) Die verlorene Söhne: Plädoyer für die Befreiung des türkisch-muslimischen Mannes. München Goldmann.

King A (2009) Islam, women and violence. Feminist Theology 17(3): 292-328.

Koran (1999) translated with notes by Dawood NJ. London: Penguin Books.

Landau P (2005) Le Sabre et le Coran. Tariq Ramadan et les frères musulmans à la conquête de l'Europe. Paris: Éditions du Rocher.

Manji I (2003) The Trouble with Islam. A Muslim's Call for Reform in Her Faith. New York: St. Martin's Press.

Mayer AE (2007) Islam and Human Rights: Tradition and Politics. Fourth Edition. Boulder, CO: Westview.

Mernissi F (1983) Sexe, idéologie, Islam. Paris: Tierce.

Mernissi F (1992) La peur-modernité: conflit Islam démocratie. Paris: Albin Michel.

Moller Okin S (1999) Is Multiculturalism Bad for Women? With Respondents, edited by Joshua Cohen, Matthew Howard, and Martha Nussbaum. Princeton, NJ: Princeton University Press.

Nasreen T (2004) Selected Columns, Translated by Debjani Sengupta. New Dehli: Srishti Publishers \& distributors.

Nietzsche F (1969) Werke IV, Aus dem Nachlass der Achtzigerjahre, Briefe (1861-1889). Herausgegeben von Karl Schlechta, Wien, Frankfurt am Main, Berlin: Ullstein.

Phares W (2007) The War of Ideas: Jihadism against Democracy. New York: Palgrave.

Ramadan T (2007) A response to Ayaan Hirsi Ali: a case of selective hearing. The International Herald Tribune, 17 December.

Rapoport DC (1984) Fear and trembling: terrorism in three religious traditions. The American Political Science Review 78(3): 658-77.

Rapoport DC (1988) Messianic sanctions for terror. Comparative Politics 20(2): 195-213.

Reed B (2002) Nothing Sacred: Women Respond to Religious Fundamentalism and Terror. New York: Thunder's Mouth Press/Nation Books.

Saadawi N El (2007) The Hidden Face of Eve: Women in the Arab World, Translated and edited by Sherif Hetata. London and New York: Zed Books.

Scruton R (2007) Culture Counts: Faith and Feeling in a World Besieged. New York: Encounter Books.

Selengut C (2003) Sacred Fury: Understanding Religious Violence. Walnut Creek, Lanham, New York, Toronto, Oxford: Rowman \& Littlefield Publishers.

Selim N (2003) De vrouwen van de profeet. Hoe vrouw(on)vriendelijk is de islam? Amsterdam:Van Gennep.

Selim N (2007a) Allah houdt niet van vrouwen. Antwerpen/Amsterdam: Houtekiet.

Selim N (2007b) Nehmt den Männern den Koran! Für eine weibliche Interpretation des Islam. Piper, Zürich: München.

Sultan W (2009) A God who Hates: The Courageous Woman Who Inflamed the Muslim World Speaks Out Against the Evils of Islam. New York: St. Martin's Press.

Tibi B (2008) Political Islam, World Politics and Europe: Democratic Peace and Euro-Islam versus Global Jihad. London and New York: Routledge.

Tibi B (2009) Euro-Islam: Die Lösung eines Zivilisationskonfliktes. Darmstadt: Primus Verlag. 